\title{
Evidence of drug-response heterogeneity rapidly generated from a single cancer cell
}

\author{
Rong Wang ${ }^{1, *}$, Chengmeng Jin ${ }^{1, *}$ and Xun $\mathrm{Hu}^{1}$ \\ ${ }^{1}$ Cancer Institute, A Key Laboratory For Cancer Prevention \& Intervention, Ministry of Education of the People's Republic of \\ China, The Second Affiliated Hospital, Zhejiang University School of Medicine, Hangzhou, China \\ *These authors have contributed equally to this work \\ Correspondence to: Xun Hu, email: huxun@zju.edu.cn \\ Keywords: heterogeneity, cancer, drug-response \\ Received: November 04, $2016 \quad$ Accepted: March 07, $2017 \quad$ Published: April 12, 2017 \\ Copyright: Wang et al. This is an open-access article distributed under the terms of the Creative Commons Attribution License 3.0 \\ (CC BY 3.0), which permits unrestricted use, distribution, and reproductionin any medium, provided the original author and source \\ are credited.
}

\section{ABSTRACT}

\begin{abstract}
One cancer cell line is believed to be composed of numerous clones with different drug sensitivity. We sought to investigate the difference of drug-response pattern in clones from a cell line or from a single cell. We showed that 22 clones derived from 4T1 cells were drastically different from each other with respect to drug-response pattern against 11 anticancer drugs and expression profile of 19 genes associated with drug resistance or sensitivity. Similar results were obtained using daughter clones derived from a single 4T1 cell. Each daughter clone showed distinct drug-response pattern and gene expression profile. Similar results were also obtained using Bcap37 cells. We conclude that a single cancer cell can rapidly produce a population of cells with high heterogeneity of drug response and the acquisition of drug-response heterogeneity is random.
\end{abstract}

\section{INTRODUCTION}

Cancer drug resistance is a major obstacle for chemotherapy. The cellular resistance to chemotherapy can be due to (1) drug extrusion mediated by drug transporter; (2) activated repair of DNA damage; (3) enhanced metabolism and detoxification of drugs; and (4) apoptosis inhibition with, in some cases, autophagy activation $[1,2]$.

Drug resistance can be arisen from heterogeneity of cancer cells, which exhibit differences on the aspects of growth, apoptosis, morphology, genetic instability [3, 4]. The major factors determining cancer cell heterogeneity are genetic makeup and epigenetic expression, origin of cancer stem cells, and tumor microenvironment, etc [5-10]. The advance of the technology to sequence the whole genome of a single cell has further unraveled the heterogenic nature of cancer cells [11, 12]. The intratumoral heterogeneity confounds significantly cancer therapy and is a challenge for precision medicine [13].

It was previously reported that after implantation of clones from human colorectal cancer into NOD-SCID mice for a series of generations, the clones showed five types of growth pattern. However, after oxaloplatin was given, the growth patterns changed [14]. Kim et al observed that clones derived from glioblastoma exhibited differences such as growth rate, differentiation, and response to temozolomide. And the different sensitivity in responding to temozolomide was due to the different expression of some genes responsible for drug resistance [11]. The heterogeneity also existed in lung cancer, breast cancer, AML, pancreatic cancer, prostate cancer and it significantly influence chemotherapy $[6,12,15,16]$.

Moreover, cancer cells with the same genetic makeup, i.e., daughter cells from one cell, can display fluctuation of gene expression; such fluctuation is due to randomness in evolution, namely random heterogeneity or intrinsic noise [17-20]. Spencer et al observed 2 daughter cells from one cancer cell showed a time difference in responding to TRAIL mediated apoptosis and this difference was caused by protein expression level (intrinsic noise) other than genetic or epigenetic factors [21]. Karen found that 2 daughter cells from one cell exhibited different response to antimitotic drugs; while one daughter cell died in M phase, the other went through $\mathrm{M}$ phase but may die at interphase or even survived; the different fates of 2 daughter cells were associated with degradation of cyclin B1 [22].

It is known that a cell line was composed of clones with different drug-response pattern, but it is not known 
Table 1: $\mathrm{IC}_{50}(\mu \mathrm{g} / \mathrm{ml})$ of clones from $4 \mathrm{~T} 1$

\begin{tabular}{|c|c|c|c|c|c|c|c|c|c|c|c|}
\hline Drugs/clones & MNT & DOX & EPI & MTX & 5-Fu & Ara-C & NVB & HCPT & VP-16 & NED & DDP \\
\hline 1 & $0.877 \pm 0.018$ & $0.558 \pm 0.089$ & $0.395 \pm 0.021$ & $0.013 \pm 0.001$ & $0.555 \pm 0.064$ & $1.03 \pm 0.113$ & $0.2 \pm 0.028$ & $0.547 \pm 0.202$ & $5.145 \pm 0.774$ & $3.04 \pm 0.226$ & $0.885 \pm 0.064$ \\
\hline 2 & $0.027 \pm 0.008$ & $0.061 \pm 0.013$ & $0.069 \pm 0.004$ & $0.003 \pm 0$ & $0.125 \pm 0.007$ & $0.105 \pm 0.064$ & $0.01 \pm 0.003$ & $0.087 \pm 0.021$ & $0.574 \pm 0.18$ & $0.85 \pm 0.156$ & $0.5 \pm 0.014$ \\
\hline 3 & $0.08 \pm 0.006$ & $0.721 \pm 0.171$ & $0.28 \pm 0.099$ & $0.82 \pm 0.428$ & $0.57 \pm 0.071$ & $3.65 \pm 0$ & $0.016 \pm 0.001$ & $1.134 \pm 0.141$ & $6.136 \pm 1.359$ & $3.485 \pm 0.247$ & $0.68 \pm 0.057$ \\
\hline 4 & $0.001 \pm 0$ & $0.045 \pm 0.006$ & $0.034 \pm 0.011$ & $0.002 \pm 0$ & $0.11 \pm 0.014$ & $0.072 \pm 0.011$ & $0.017 \pm 0.007$ & $0.107 \pm 0.009$ & $7.081 \pm 1.394$ & $1.145 \pm 0.445$ & $0.415 \pm 0.064$ \\
\hline 5 & $0.057 \pm 0.002$ & $0.751 \pm 0.004$ & $0.098 \pm 0.032$ & $0.127 \pm 0.1$ & $0.34 \pm 0.141$ & $5.935 \pm 0.417$ & $0.162 \pm 0.097$ & $3.662 \pm 0.542$ & $6.169 \pm 0.581$ & $2.15 \pm 0.311$ & $0.38 \pm 0.057$ \\
\hline 6 & $0.05 \pm 0.006$ & $0.156 \pm 0.053$ & $0.085 \pm 0.021$ & $0.004 \pm 0.001$ & $0.101 \pm 0.013$ & $0.405 \pm 0.205$ & $0.015 \pm 0.001$ & $2.312 \pm 0.478$ & $5.396 \pm 1.684$ & $1.47 \pm 0.156$ & $0.52 \pm 0$ \\
\hline 7 & $0.347 \pm 0.031$ & $0.511 \pm 0.015$ & $0.375 \pm 0.007$ & $0.092 \pm 0.017$ & $0.405 \pm 0.078$ & $6.165 \pm 0.658$ & $0.028 \pm 0.003$ & $3.12 \pm 0.026$ & $7.688 \pm 1.401$ & $2.72 \pm 0.141$ & $0.79 \pm 0.028$ \\
\hline 8 & $0.057 \pm 0.004$ & $0.054 \pm 0.003$ & $0.395 \pm 0.049$ & $0.01 \pm 0.001$ & $0.105 \pm 0.008$ & $0.085 \pm 0.021$ & $0.01 \pm 0$ & $0.066 \pm 0.025$ & $4.652 \pm 0.102$ & $0.72 \pm 0.24$ & $0.45 \pm 0.028$ \\
\hline 9 & $0.074 \pm 0.001$ & $1.021 \pm 0.345$ & $0.215 \pm 0.163$ & $0.003 \pm 0$ & $0.31 \pm 0.099$ & $0.115 \pm 0.078$ & $0.039 \pm 0.012$ & $1.965 \pm 0.933$ & $2.398 \pm 0.262$ & $2.305 \pm 0.332$ & $0.5 \pm 0.141$ \\
\hline 10 & $0.022 \pm 0.001$ & $0.076 \pm 0.006$ & $0.043 \pm 0.005$ & $0.019 \pm 0.001$ & $0.19 \pm 0.085$ & $0.35 \pm 0$ & $0.007 \pm 0.001$ & $0.405 \pm 0.06$ & $1.069 \pm 0.169$ & $1.665 \pm 0.021$ & $0.265 \pm 0.049$ \\
\hline 11 & $0.933 \pm 0.029$ & $0.419 \pm 0.025$ & $0.145 \pm 0.021$ & $0.255 \pm 0.095$ & $0.265 \pm 0.007$ & $0.13 \pm 0.014$ & $0.345 \pm 0.092$ & $0.377 \pm 0.021$ & $8.143 \pm 0.607$ & $2.245 \pm 0.219$ & $0.94 \pm 0.014$ \\
\hline 12 & $0.04 \pm 0.021$ & $0.137 \pm 0.011$ & $0.089 \pm 0.016$ & $0.004 \pm 0.001$ & $0.13 \pm 0$ & $1.28 \pm 0.028$ & $0.009 \pm 0.001$ & $0.272 \pm 0.024$ & $4.376 \pm 0.509$ & $0.82 \pm 0.085$ & $0.49 \pm 0$ \\
\hline 13 & $1.176 \pm 0.092$ & $0.291 \pm 0.118$ & $0.205 \pm 0.007$ & $0.036 \pm 0.016$ & $0.475 \pm 0.035$ & $0.2 \pm 0$ & $0.05 \pm 0.028$ & $1.334 \pm 0.214$ & $1.833 \pm 0.263$ & $4.32 \pm 0.141$ & $2.175 \pm 0.12$ \\
\hline 14 & $0.074 \pm 0.011$ & $0.153 \pm 0.008$ & $0.045 \pm 0.026$ & $0.006 \pm 0.001$ & $0.105 \pm 0.007$ & $0.107 \pm 0.018$ & $0.014 \pm 0.001$ & $0.369 \pm 0.068$ & $0.846 \pm 0.092$ & $0.895 \pm 0.064$ & $0.63 \pm 0.311$ \\
\hline 15 & $0.047 \pm 0.025$ & $0.363 \pm 0.14$ & $0.085 \pm 0.008$ & $0.005 \pm 0$ & $0.585 \pm 0.134$ & $0.13 \pm 0.014$ & $0.021 \pm 0.005$ & $1.792 \pm 0.066$ & $0.974 \pm 0.513$ & $2.625 \pm 0.233$ & $0.555 \pm 0.021$ \\
\hline 16 & $0.098 \pm 0.018$ & $0.34 \pm 0.038$ & $0.185 \pm 0.021$ & $0.021 \pm 0.008$ & $0.265 \pm 0.064$ & $1.02 \pm 0.665$ & $0.008 \pm 0.004$ & $1.199 \pm 0.022$ & $2.813 \pm 0.486$ & $2.285 \pm 0.064$ & $0.94 \pm 0.099$ \\
\hline 17 & $0.065 \pm 0.013$ & $0.635 \pm 0.047$ & $0.365 \pm 0.035$ & $0.009 \pm 0.001$ & $0.835 \pm 0.247$ & $0.2 \pm 0.014$ & $0.026 \pm 0.006$ & $0.52 \pm 0.028$ & $2.027 \pm 0.35$ & $2.975 \pm 0.544$ & $0.61 \pm 0.042$ \\
\hline 18 & $0.023 \pm 0.002$ & $0.114 \pm 0.006$ & $0.23 \pm 0.127$ & $0.004 \pm 0.001$ & $0.185 \pm 0.021$ & $0.23 \pm 0.057$ & $0.016 \pm 0.005$ & $0.762 \pm 0.187$ & $1.32 \pm 0.448$ & $1.575 \pm 0.841$ & $0.79 \pm 0.113$ \\
\hline 19 & $0.079 \pm 0.015$ & $0.454 \pm 0.185$ & $0.28 \pm 0.071$ & $0.006 \pm 0.001$ & $0.975 \pm 0.233$ & $0.14 \pm 0.014$ & $0.024 \pm 0.004$ & $5.044 \pm 3.003$ & $2.199 \pm 0.708$ & $3.12 \pm 0.481$ & $0.53 \pm 0.028$ \\
\hline 20 & $0.012 \pm 0.001$ & $0.126 \pm 0.002$ & $0.24 \pm 0.042$ & $0.002 \pm 0$ & $0.155 \pm 0.007$ & $0.37 \pm 0.028$ & $0.02 \pm 0.008$ & $0.044 \pm 0.012$ & $0.664 \pm 0.095$ & $0.775 \pm 0.134$ & $0.86 \pm 0.127$ \\
\hline 21 & $0.089 \pm 0.006$ & $0.443 \pm 0.199$ & $0.29 \pm 0.127$ & $0.004 \pm 0$ & $0.245 \pm 0.106$ & $0.22 \pm 0.028$ & $0.025 \pm 0.003$ & $2.68 \pm 0.877$ & $6.776 \pm 0.939$ & $3.69 \pm 0.17$ & $0.85 \pm 0.057$ \\
\hline 22 & $0.041 \pm 0.001$ & $0.392 \pm 0.023$ & $0.165 \pm 0.007$ & $0.013 \pm 0.001$ & $0.11 \pm 0.015$ & $0.31 \pm 0.042$ & $0.008 \pm 0$ & $0.385 \pm 0.133$ & $2.15 \pm 0.077$ & $2.035 \pm 0.573$ & $0.705 \pm 0.049$ \\
\hline $\begin{array}{l}\text { Resistant } \\
\text { clone }\end{array}$ & 13 & 9 & 1,8 & 3 & 19 & 7 & 11 & 19 & 11 & 13 & 13 \\
\hline $\begin{array}{l}\text { Sensitive } \\
\text { clone }\end{array}$ & 4 & 4 & 4 & 20 & 6 & 4 & 10 & 20 & 2 & 8 & 10 \\
\hline $\begin{array}{l}\text { Ratio } \\
\text { resistant/ } \\
\text { sensitive) }\end{array}$ & 1176 & 22.7 & 11.6 & 410 & 9.7 & 85.6 & 49.3 & 114.6 & 14.2 & 6 & 8.2 \\
\hline
\end{tabular}

Cells were incubated with a series of different concentrations of drugs for 48 hours and subjected for a MTT assay to measure half inhibitory concentration ( $\left.\mathrm{IC}_{50}\right)$. Data were means \pm SD of two independent experiments.

how big the difference these clones can be. In addition, it is not known if a single cancer cell can generate an array of daughter cells with diverse drug-response phenotypes.

We chose 4T1 and Bcap37 cell lines as the model cells for this study, because we were familiar with the nature of these cells: we have used these cells to study cancer cell survival under glucose deprivation [23], glycolytic flux control [24], glucose metabolism and cellular energetics $[25,26]$, ROS generation and cytosolic NAD/NADH ratios [27, 28], chromosomal instability under stress condition [29], intervention of metastasis by schisandrin B [30, 31].

\section{RESULTS}

\section{Clones derived from 4T1 cells exhibit diversity of drug response pattern}

Using limited dilution culture, we obtained 22 single cell-derived clones from 4T1 cell line. These clones were expanded and assayed for their sensitivity to a panel of 11 anticancer drugs, including antimetabolites, anthracycline compounds, plants chemicals and platinum drugs (Table 1). Two prominent points were observed. First, sensitivities to each drug varied significantly from clone to clone, e.g., clone 13 was 1176 folds more resistant to MNT than clone 4, clone 19 was 115 folds more resistant to HCPT than clone 20, clone 3 was 410 folds more resistant to MTX than clone 20, among others (Figure 1). Second, each clone exhibited distinct drugresponse pattern (Figure 2). In comparison to 4T1 cells, one clone could be more resistant to some drug but more sensitive to others, e.g., clone 13 was resistant to MNT but sensitive to Ara-C, clone 1 was resistant to MNT and NVB but sensitive to MTX, among others.

Next, we measured the expression of a panel of 19 genes associated with drug response, including ATPbinding cassette $(\mathrm{ABC})$ transporter family, the mismatch repair (MMR) system, chromosomal instability genes, DNA damage repair genes and apoptosis related genes. 
Like their response to drugs, each clone exhibited distinct gene expression profiles (Figure $3 \& 4$ ).

\section{Daughter clones from a single 4T1 cell show heterogeneous phenotypes}

The above results indicated that clones from 4T1 cells were significantly different from each other. This seemed to suggest that each 4T1 cell was unique and such a high heterogeneity of 4T1 cells was beyond our expectation. We thought that the difference might be largely phenotypic. It would be expensive to investigate the question using single cell sequencing technology. The alternative approach is to check if clones derived from a single 4T1 cell were phenotypically different. Using limited dilution culture, we isolated a single cell-derived clone N1. This clone was then further subcloned and 14 daughter clones were obtained. Again, the sensitivities to anticancer drugs varied remarkably from clone to clone (Table 2, Figure 5), e.g., subclone 11 was 164 folds more resistant to Ara-C than subclone 2, subclone 9 was 55 folds more resistant to NVB than clone 14, subclone 4 was 7 folds more resistant to 5-Fu than subclone 14, among others. On the other hand, A subclone that was resistant to a drug could be sensitive to another, e.g., subclone 11 was resistant to MTX and Ara-C but sensitive to Dox and EPI. Each subclone exhibited distinct drug response profile from others (Figure 6).
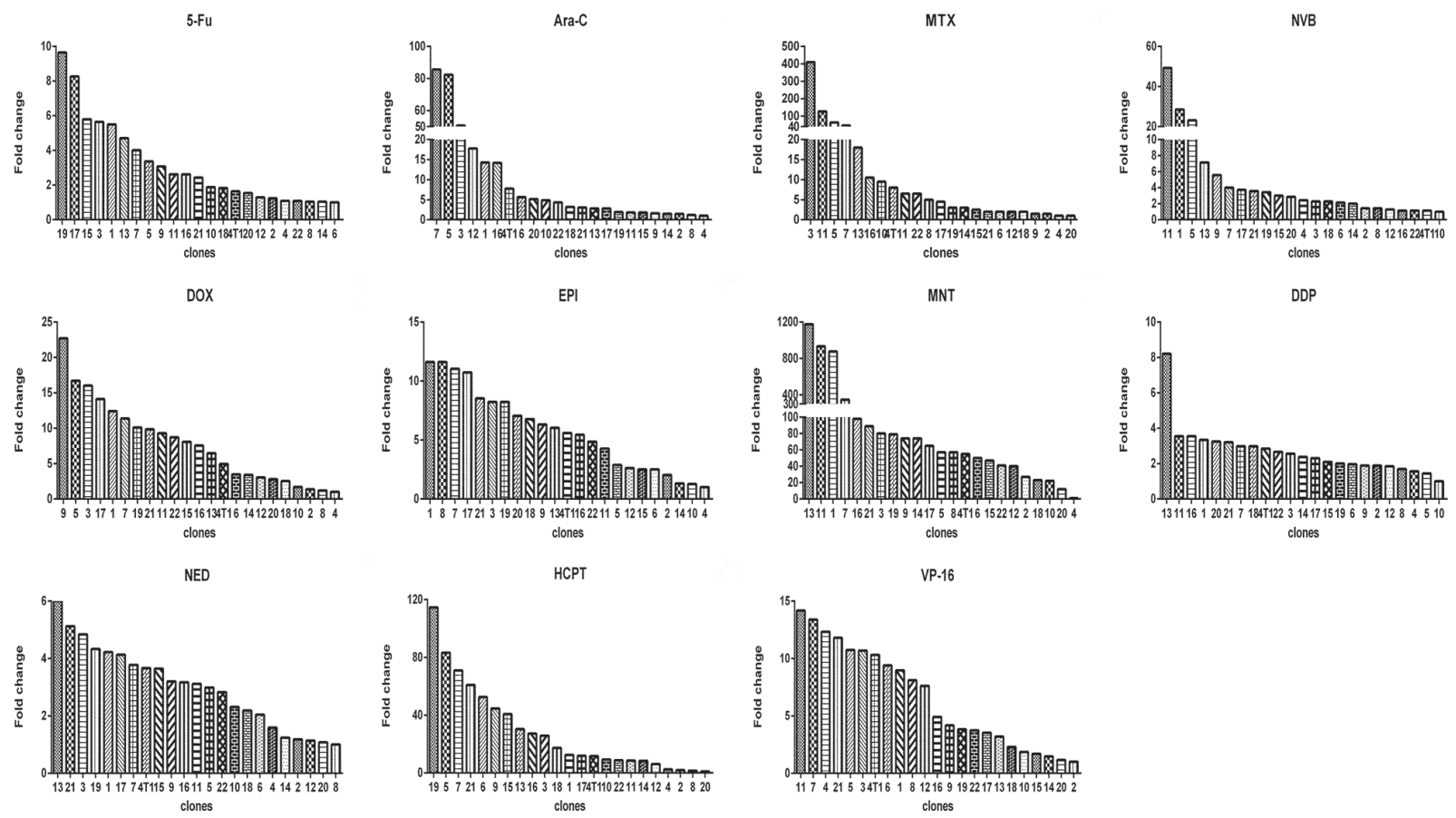

Like clones derived from 4T1, the 10 single-cell derived clones from Bcap37 cell line also exhibited diversity in drug response patterns (Supplementary Table 2, Supplementary Figure 5-6). Unlike clones derived from

Figure 1: Relative drug sensitivity of clones from 4T1 cells. For each drug, there was a clone that had the smallest $\mathrm{IC}_{50}$, which was used to divide $\mathrm{IC}_{50}$ of this clone and of all other clones (x axis) to derive the value of fold change (y axis). 
4T1, the difference of the fold change between clones in drug sensitivity was much smaller, e.g., the biggest fold change was about 8 (HCPT), whereas in $4 \mathrm{~T} 1$ clones the biggest fold change was 1176 (MNT). It was noted that the absolute number of $\mathrm{IC}_{50} \mathrm{~s}$ of Bcap37 and its clones were substantially higher than those of 4T1 and its clones, indicating the specific feature of individual cell lines.

The daughter clones from a single Bcap37 cell origin also exhibited a similar feature to those derived from Bcap37 cell line as described above
(Supplementary Table 3): the drug sensitivity between subclones varied (Supplementary Figure 7) and each subclone exhibited distinct drug-response pattern (Supplementary Figure 8).

Next, we checked the expression of a panel of 18 drug resistance associated genes in the clones from the Bcap37 cell line or from a single Bcap37 cell. Like their response to drugs, each clone or subclone exhibited distinct gene expression profiles (Supplementary Figure 9-12).
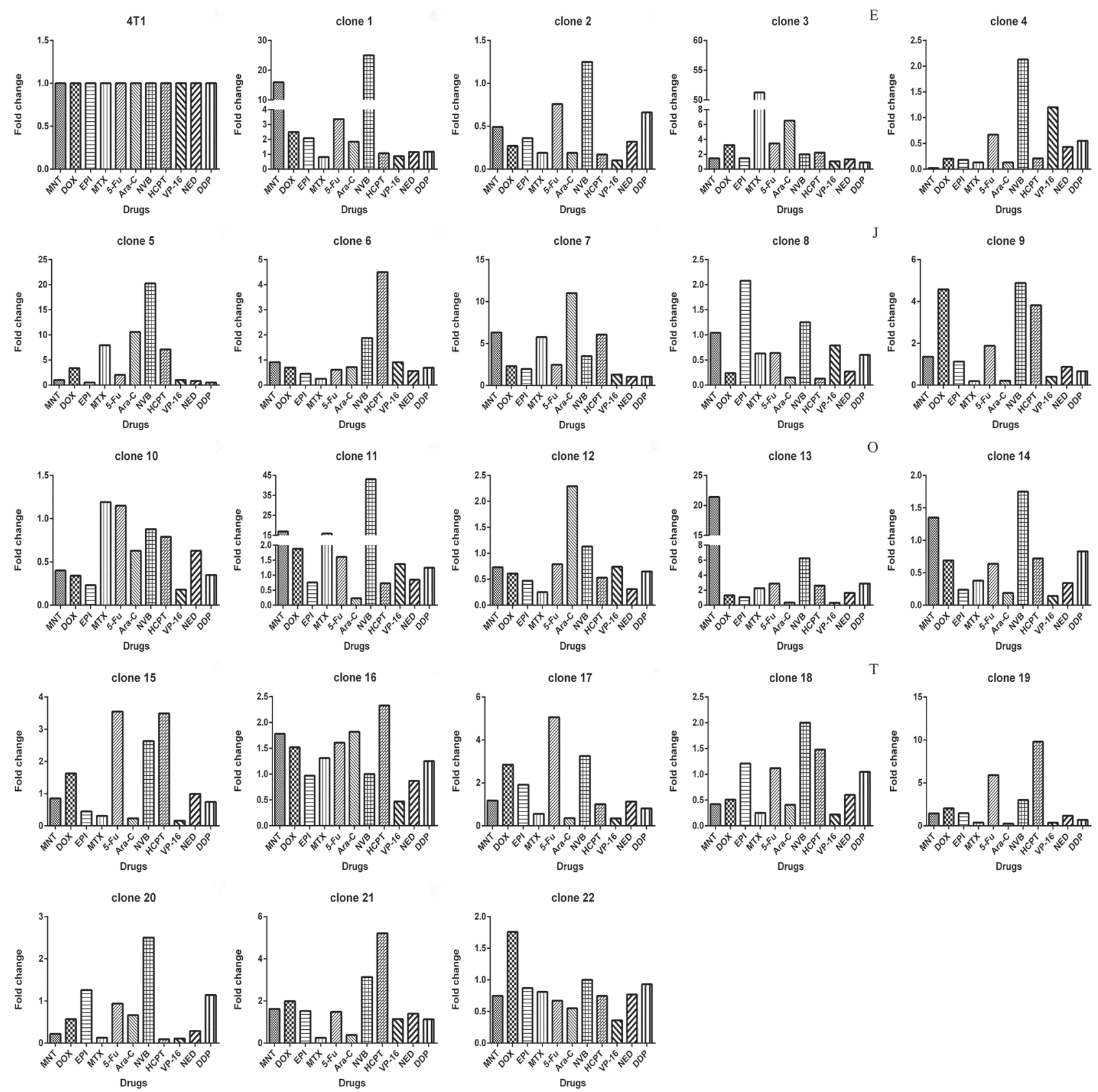

Figure 2: Each clone derived from $4 \mathrm{~T} 1$ cells exhibits drug-response pattern distinct from others. $\mathrm{The} \mathrm{IC}_{50} \mathrm{~s}$ of $4 \mathrm{~T} 1 \mathrm{cells}$ toward 11 drugs ( $\mathrm{x}$ axis) were used to divide $\mathrm{IC}_{50} \mathrm{~s}$ of $4 \mathrm{~T} 1$ cells and of all other clones to derive fold change values (y axis). 


\section{DISCUSSION}

The main purpose of this study is to investigate how big the difference of daughter clones from a single cell origin can be. The key result of the study is the demonstration of significant difference of drug resistance/ sensitivity between daughter clones from a single 4T1 cell origin. These daughter clones had the same genetic
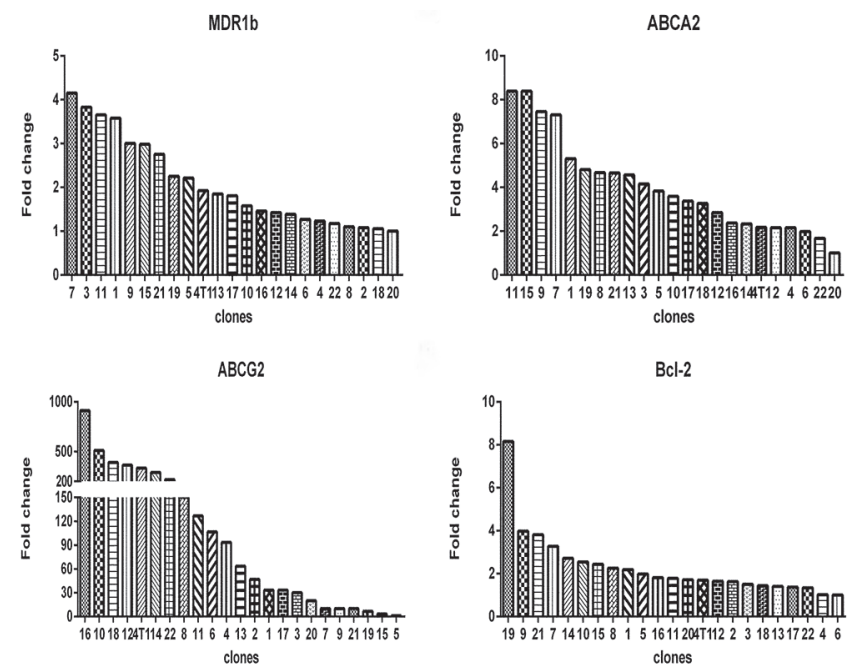

MLH1

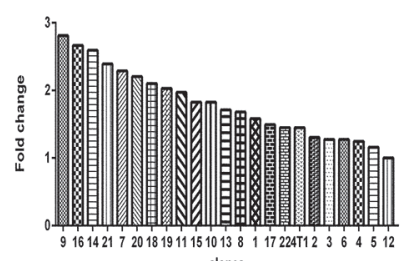

clones

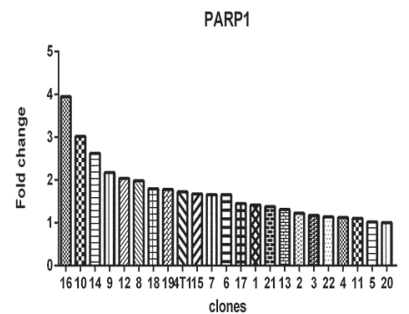

MRP4
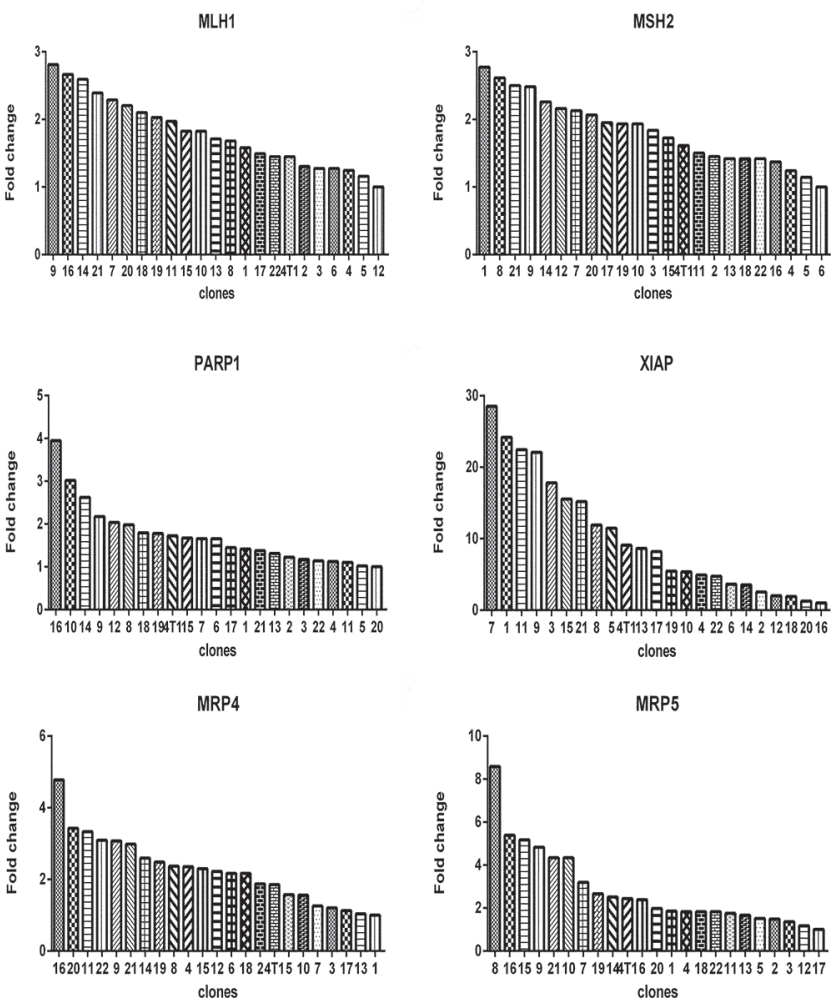

background, they were cultured under same condition, and they were not stimulated with anticancer drugs, yet they exhibited a remarkable diversity of drug response pattern. The fold change (drug sensitivity index) could be markedly different from each other, e.g., the most resistant daughter clone (clone 11, Table 2 ) was 164 folds higher than the least resistant one (clone 2) responding to Ara-C. Previously, there were reports regarding the difference
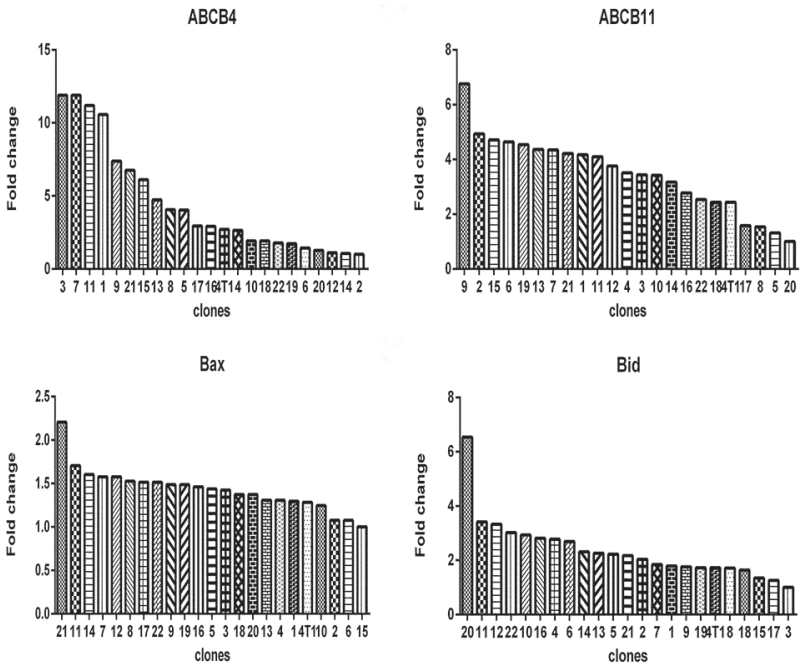

NEK2
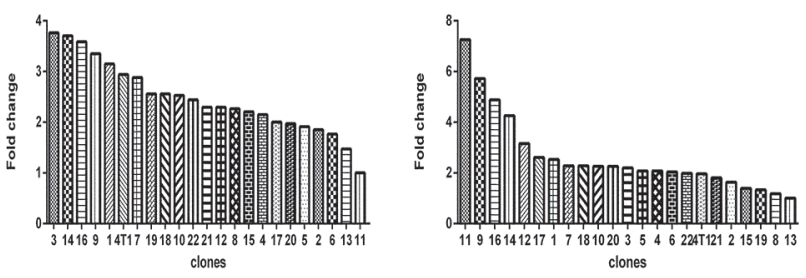

MRP1
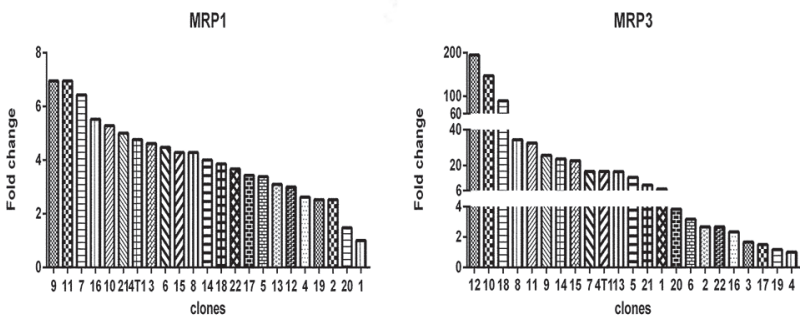

HER2

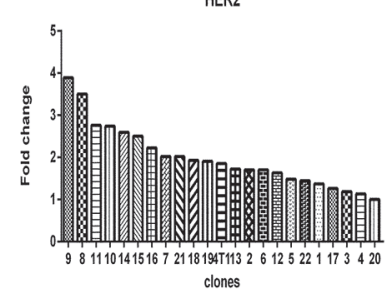

Figure 3: Relative levels of gene expression of clones from 4T1 cells. For each gene, there was a clone that had the lowest expression level. The fold change is based on the formula $2^{-[\Delta C T) \text { clone(i)-(ACT)clone(a)] }}$ according to the method previously described [39], where, clone(i) denote any one of the 22 clones, and clone(a) denotes the one with lowest expression of a given gene. $\Delta \mathrm{CT}$ was derived as described in Materials and Methods. 
of daughter cells responding to AZ138 (an antimitotic drug) and camptothecin $[22,32]$, but both studies focused on different fates of the daughter cells other than the points addressed in this study. It is noted that the same phenomenon was observed in clones derived from a single Bcap37 cell, but the fold change of drug response (Supplementary Figure 5) was not as dramatic as those for clones obtained from a single 4T1 cell. The similarity and difference between 4T1 and Bcap37 may reflect the specific feature of individual cell lines.
The quick diversification of daughter clones from a single cell under the same culture without drug pretreatment condition suggests the elusive epigenetics. The expression levels of genes between daughter clones differed dramatically, e.g., the fold change of gene $A B C G 2$ could be as large as 120 (Figure 7). Each daughter clone displayed a distinct pattern of gene expression. Apparently, a drug response pattern was associated with a complex gene expression, as indicated by the expression levels of a panel of 19 genes.
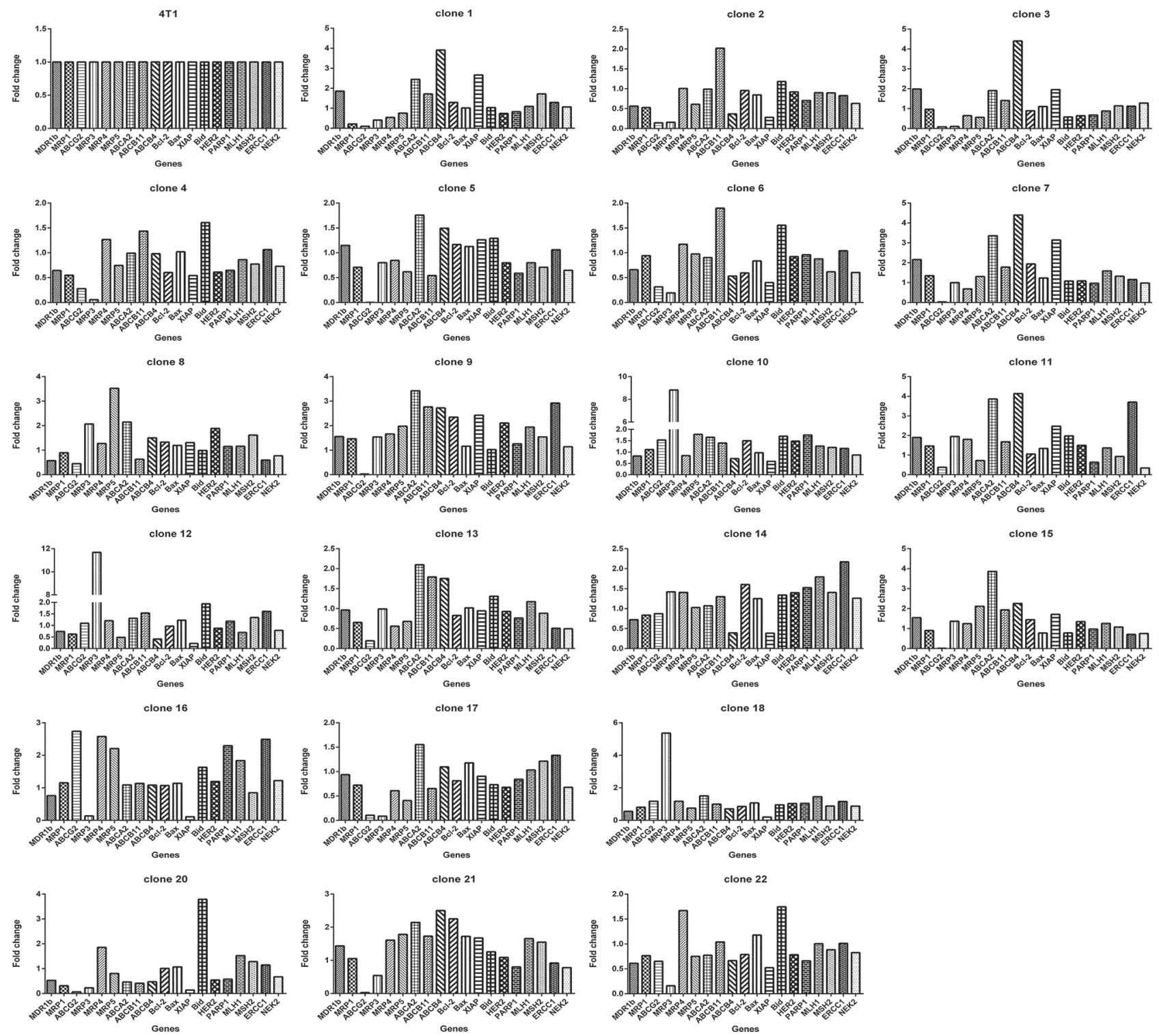

Figure 4: Each clone derived from 4T1 cells exhibits gene expression pattern distinct from others. Taking 4T1 as a reference, The relative expression level of the 19 genes in each clone is based on the formula $2^{-[(\Delta \mathrm{CT}) \text { clone(i)-( } \triangle \mathrm{CT}) 4 \mathrm{~T} 1]}$ according to the method previously described [39], where, clone(i) denote any one of the 22 clones. $\Delta \mathrm{CT}$ was derived as described in Materials and Methods. 
Table 2: $\mathrm{IC}_{50}(\mu \mathrm{g} / \mathrm{ml})$ of subclones of monoclonal $\mathrm{N} 1$

\begin{tabular}{|c|c|c|c|c|c|c|c|c|c|c|}
\hline Drugs/Clones & MNT & DOX & EPI & MTX & 5-Fu & Ara-C & NVB & VP-16 & NED & DDP \\
\hline 1 & $0.175 \pm 0.007$ & $0.31 \pm 0.044$ & $0.2 \pm 0$ & $0.009 \pm 0.002$ & $1.08 \pm 0.226$ & $0.315 \pm 0.177$ & $0.033 \pm 0.009$ & $6.83 \pm 0.26$ & $3.48 \pm 0.028$ & $0.93 \pm 0.085$ \\
\hline 2 & $0.176 \pm 0.027$ & $0.43 \pm 0.074$ & $0.625 \pm 0.064$ & $0.01 \pm 0.003$ & $1.29 \pm 0.339$ & $0.17 \pm 0.014$ & $0.165 \pm 0.021$ & $8.395 \pm 0.52$ & $4.415 \pm 0.672$ & $2.14 \pm 0.679$ \\
\hline 3 & $0.118 \pm 0.004$ & $0.407 \pm 0.04$ & $0.255 \pm 0.049$ & $0.01 \pm 0$ & $0.84 \pm 0.141$ & $0.185 \pm 0.049$ & $0.165 \pm 0.021$ & $7.984 \pm 0.2$ & $4.775 \pm 0.304$ & $1.34 \pm 0.113$ \\
\hline 4 & $0.097 \pm 0.04$ & $0.462 \pm 0.029$ & $0.34 \pm 0$ & $0.022 \pm 0.006$ & $2.16 \pm 0.297$ & $0.4 \pm 0.099$ & $0.26 \pm 0.127$ & $11.209 \pm 0.273$ & $6.41 \pm 0.396$ & $2.425 \pm 0.276$ \\
\hline 5 & $0.127 \pm 0.037$ & $0.385 \pm 0.013$ & $0.275 \pm 0.007$ & $0.101 \pm 0.04$ & $1.155 \pm 0.078$ & $0.2 \pm 0.028$ & $0.06 \pm 0.003$ & $8.915 \pm 0.639$ & $5.895 \pm 0.46$ & $1.605 \pm 0.148$ \\
\hline 6 & $0.106 \pm 0.035$ & $0.369 \pm 0.048$ & $0.25 \pm 0.014$ & $0.013 \pm 0.006$ & $1.795 \pm 0.474$ & $0.19 \pm 0.014$ & $0.15 \pm 0.113$ & $7.76 \pm 0.598$ & $5.175 \pm 0.94$ & $1.375 \pm 0.078$ \\
\hline 7 & $0.454 \pm 0.02$ & $0.95 \pm 0.391$ & $0.61 \pm 0.028$ & $0.009 \pm 0.001$ & $1.205 \pm 0.177$ & $3.1 \pm 0.608$ & $0.265 \pm 0.021$ & $12.568 \pm 1.616$ & $4.405 \pm 0.035$ & $1.275 \pm 0.021$ \\
\hline 8 & $0.095 \pm 0.008$ & $0.395 \pm 0.107$ & $0.495 \pm 0.134$ & $0.003 \pm 0$ & $0.585 \pm 0.177$ & $0.215 \pm 0.049$ & $0.052 \pm 0.002$ & $4.208 \pm 0.997$ & $3.7 \pm 0.198$ & $0.895 \pm 0.007$ \\
\hline 9 & $0.105 \pm 0.004$ & $0.612 \pm 0.061$ & $0.645 \pm 0.092$ & $0.008 \pm 0.001$ & $0.575 \pm 0.233$ & $1.51 \pm 0.354$ & $0.495 \pm 0.078$ & $6.618 \pm 2.085$ & $4.41 \pm 0.354$ & $0.86 \pm 0.085$ \\
\hline 10 & $0.068 \pm 0.023$ & $0.284 \pm 0.071$ & $0.53 \pm 0.113$ & $0.011 \pm 0.004$ & $0.925 \pm 0.007$ & $0.51 \pm 0.212$ & $0.355 \pm 0.007$ & $5.189 \pm 0.076$ & $6.435 \pm 1.549$ & $2.13 \pm 0.453$ \\
\hline 11 & $0.236 \pm 0.013$ & $0.211 \pm 0.001$ & $0.135 \pm 0.049$ & $0.537 \pm 0.016$ & $1.23 \pm 0.368$ & $27.85 \pm 3.748$ & $0.108 \pm 0.031$ & $9.344 \pm 0.073$ & $2.74 \pm 0.17$ & $0.75 \pm 0.099$ \\
\hline 12 & $0.153 \pm 0.045$ & $0.406 \pm 0.006$ & $0.305 \pm 0.035$ & $0.309 \pm 0.023$ & $0.72 \pm 0.042$ & $7.18 \pm 1.64$ & $0.022 \pm 0.001$ & $8.249 \pm 0.233$ & $3.59 \pm 0.113$ & $0.925 \pm 0.035$ \\
\hline 13 & $0.251 \pm 0.018$ & $0.304 \pm 0.013$ & $0.13 \pm 0.014$ & $0.04 \pm 0.009$ & $0.41 \pm 0.085$ & $2.495 \pm 1.025$ & $0.064 \pm 0.04$ & $7.726 \pm 0.09$ & $3.475 \pm 0.078$ & $0.95 \pm 0$ \\
\hline 14 & $0.104 \pm 0.02$ & $0.382 \pm 0.17$ & $0.155 \pm 0.007$ & $0.005 \pm 0.001$ & $0.285 \pm 0.021$ & $2.18 \pm 0.255$ & $0.009 \pm 0.001$ & $6.861 \pm 0.175$ & $3.16 \pm 0.014$ & $1.03 \pm 0.014$ \\
\hline $\begin{array}{l}\text { Resistant } \\
\text { clone }\end{array}$ & 7 & 7 & 9 & 11 & 4 & 11 & 9 & 7 & 10 & 4 \\
\hline $\begin{array}{l}\text { Sensitive } \\
\text { clone }\end{array}$ & 10 & 11 & 3 & 8 & 14 & 2 & 14 & 8 & 11 & 11 \\
\hline $\begin{array}{l}\text { Ratio } \\
\text { (resistant/ } \\
\text { sensitive) }\end{array}$ & 6.7 & 4.5 & 5.0 & 179 & 7.6 & 163.8 & 55 & 3.0 & 2.4 & 3.2 \\
\hline
\end{tabular}

Cells were incubated with a series of different concentrations of drugs for 48 hours and subjected for a MTT assay to measure half inhibitory concentration (IC ${ }_{50}$. Data were means $\pm \mathrm{SD}$ of two independent experiments.

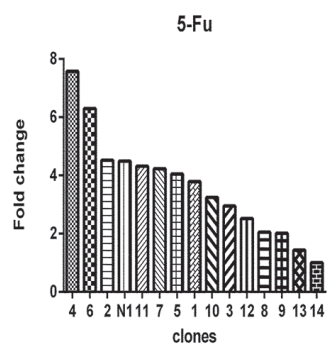

DOX

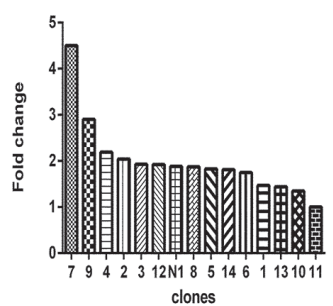

NED

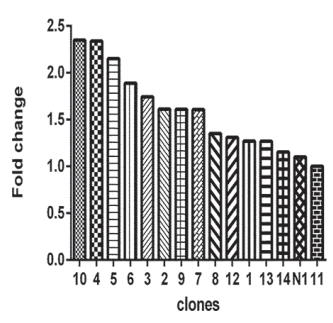

Ara-C

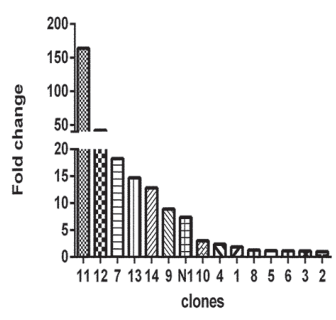

EPI

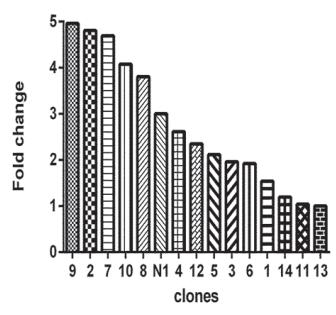

VP-16

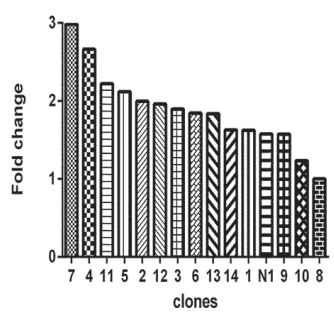

MTX

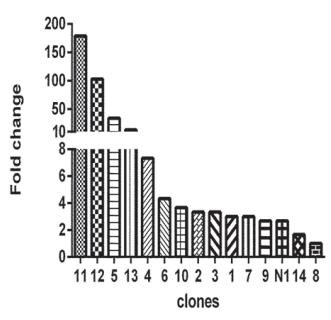

MNT
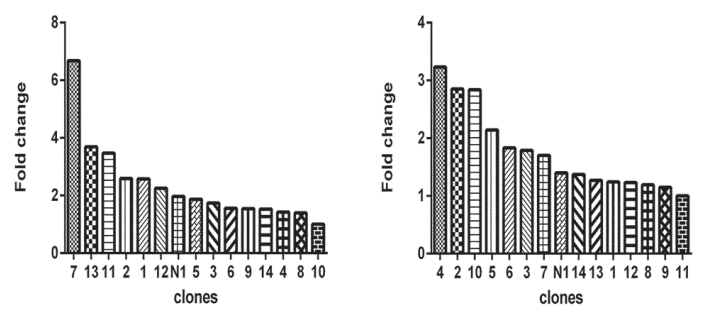

Figure 5: Relative drug sensitivity of subclones from monoclonal N1 (a clone from 4T1). For each drug, there was a clone that had the smallest $\mathrm{IC}_{50}$, which was used to divide $\mathrm{IC}_{50}$ of this subclone and of all other subclones (x axis) to derive the value of fold change (y axis). 
We showed that clones with different drug response patterns existed in a cell line, which was not novel, as many studies previously have shown that clones form a cell line can vary from each other in many ways, including drug resistance [11, 33, 34], metastasis [34]. Two relatively fresh points in this study were: (1) remarkable difference between clones from 4T1 cells, the fold change of drug resistance, e.g, to MNT, between clones (Figure 1), can be as large as 3 orders of magnitude, the fold change of gene expression, such as $A B C G 2$, can be as large as 2 orders of magnitude (Figure 3); (2) each clone in the 22 clones seems unique regarding drug response (Figure 2) or gene expression (Figure 4). Such a highly heterogeneous nature observed in 4T1 cells may simply reflect phenotypic difference, because a single cell through simple division can quickly produce an array of daughter clones dramatically different from each other. We assume that each cell can produce 2 daughter cells, the daughter cells further produce daughter cells; each division may produce some fluctuations, and the fluctuation could add up.
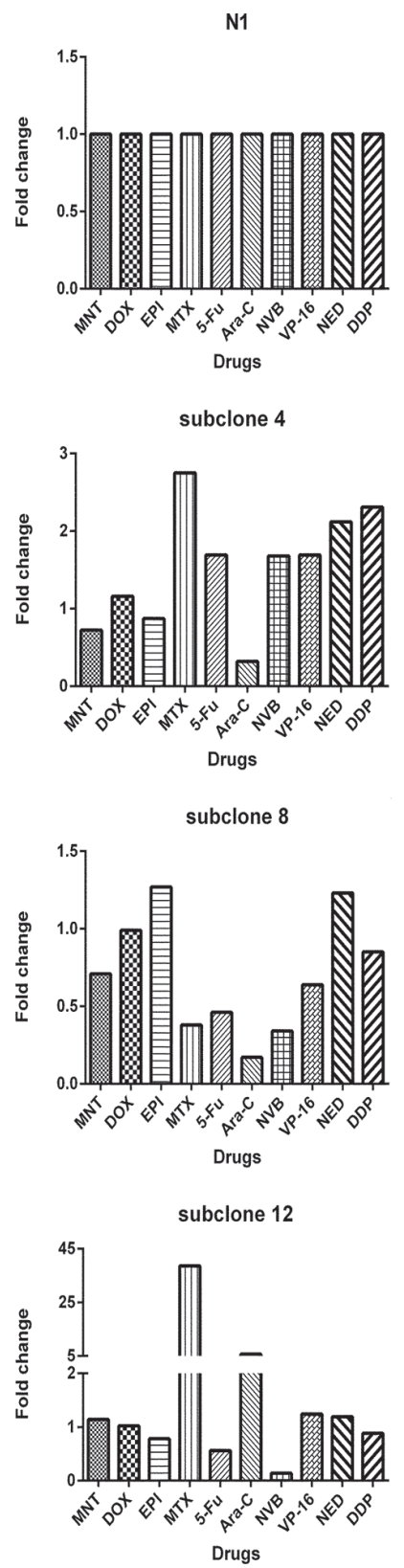
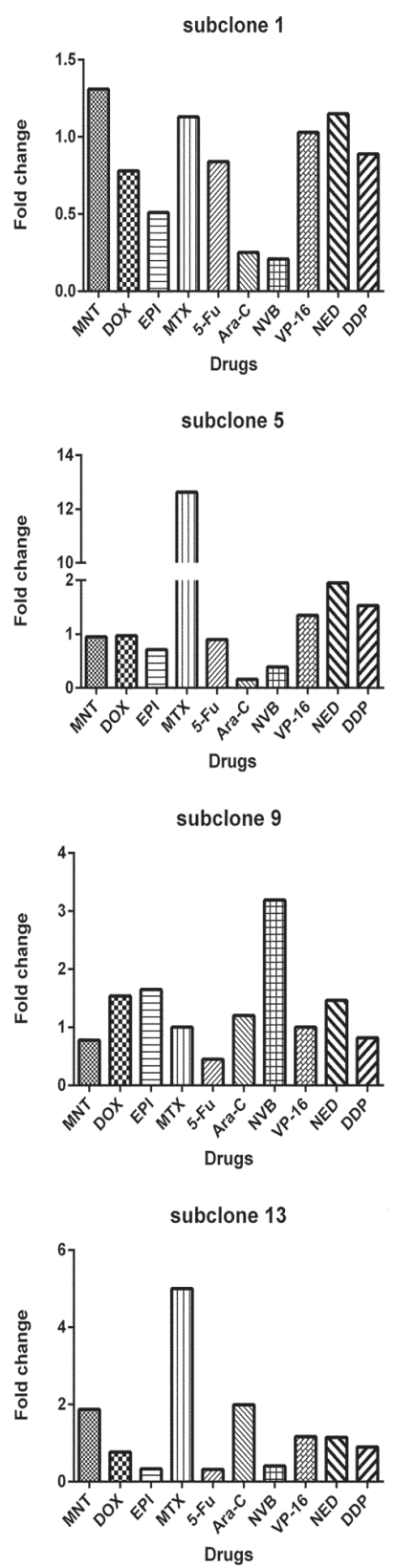
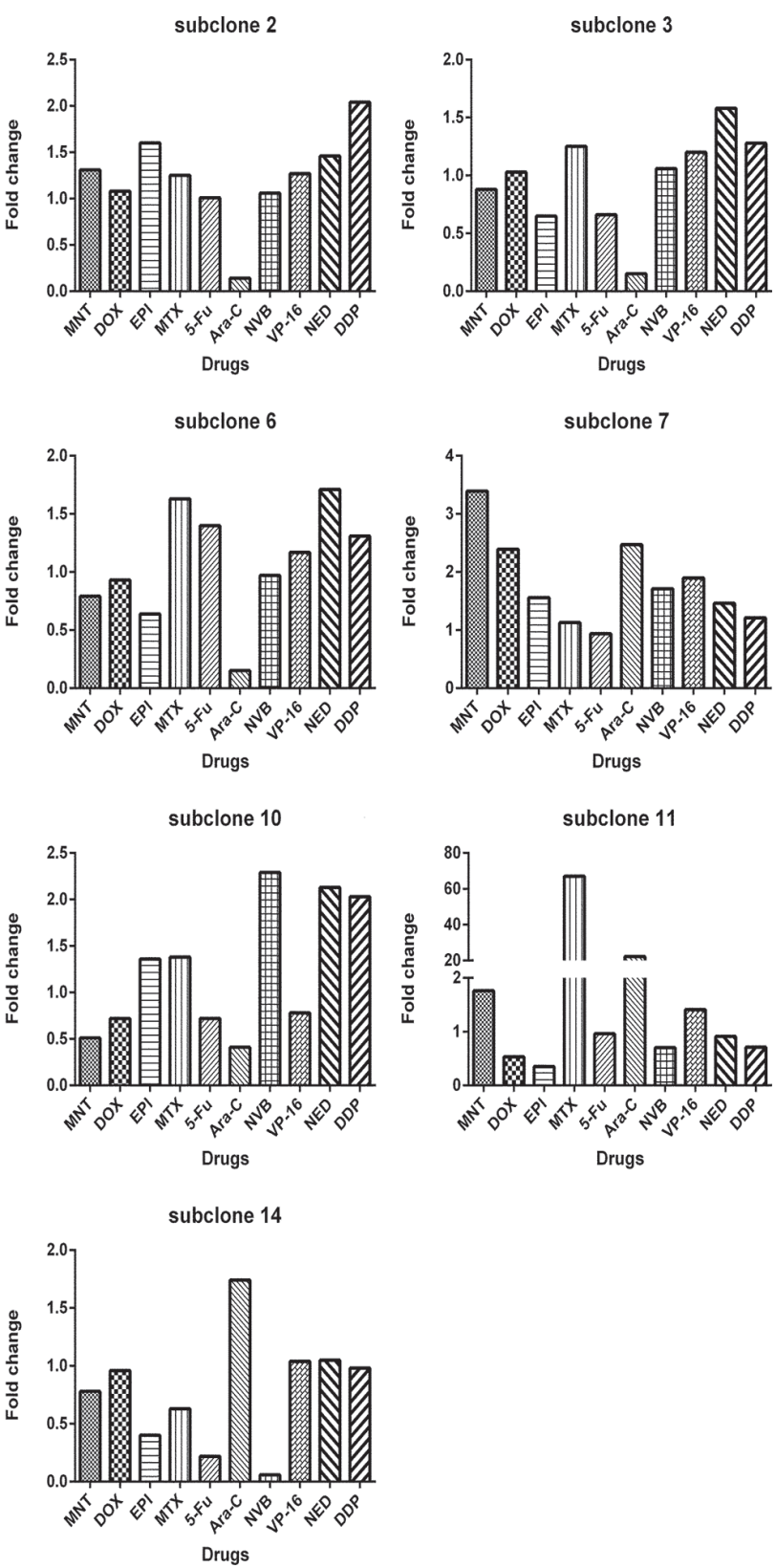

Figure 6: Each subclone derived from monoclonal N1 exhibits drug-response pattern distinct from others. The $\mathrm{IC}_{50} \mathrm{~s}$ of monoclonal $\mathrm{N} 1$ toward 10 drugs (x axis) were used to divide $\mathrm{IC}_{50} \mathrm{~s}$ of the monoclonal $\mathrm{N} 1$ and of all other subclones to derive fold change values (y axis). 

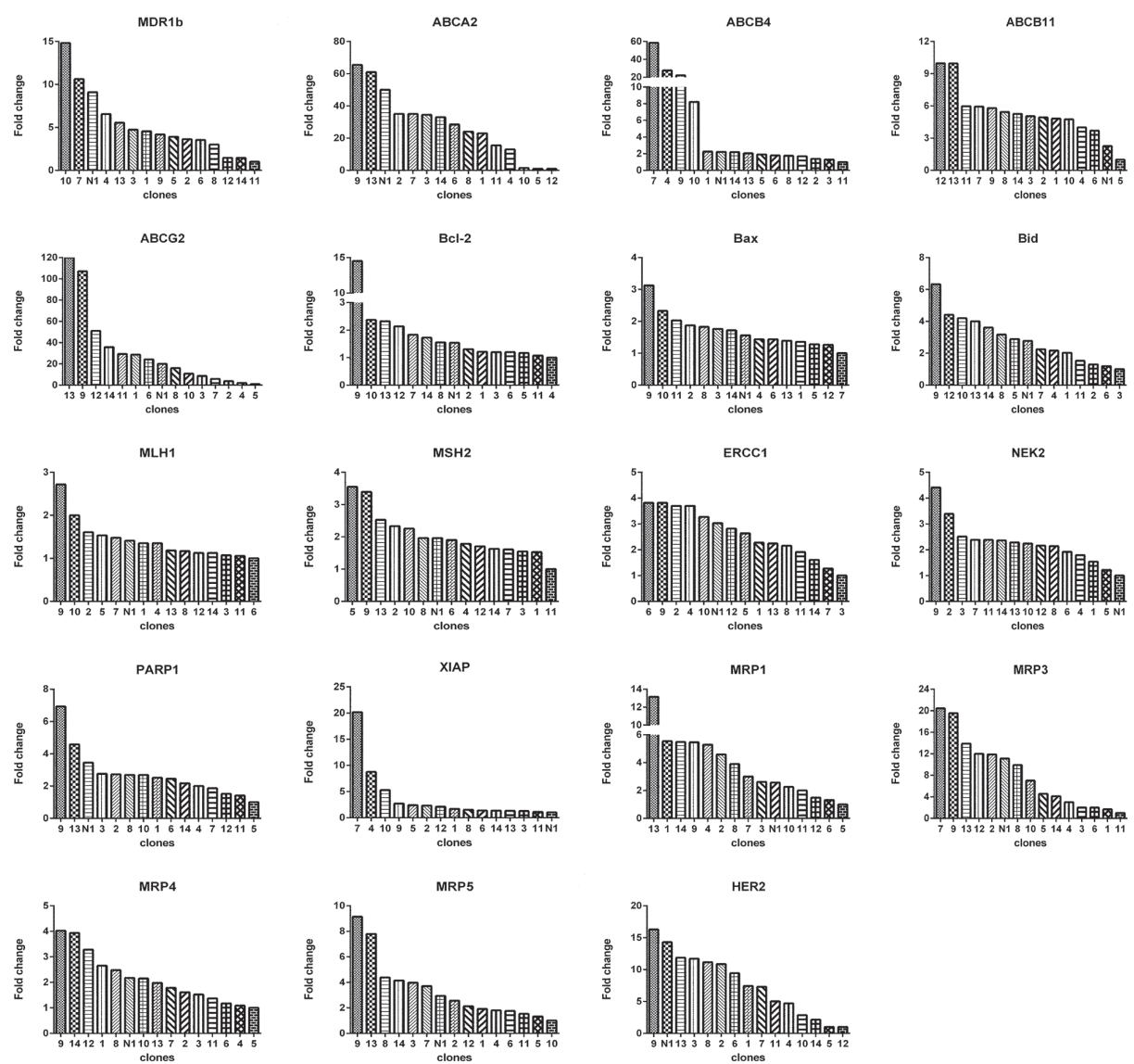

Figure 7: Relative levels of gene expression of subclones from monoclonal N1. For each gene, there was a subclone that had the lowest expression level. The fold change is based on the formula $2^{-[(\triangle C T) \text { subclone(i)-( } \triangle \mathrm{CT}) \text { subclone(a)] }}$ according to the method previously described [39], where, subclone(i) denote any one of the 14 subclones, and subclone(a) denotes the one with lowest expression of a given gene. $\Delta C T$ was derived as described in Materials and Methods.

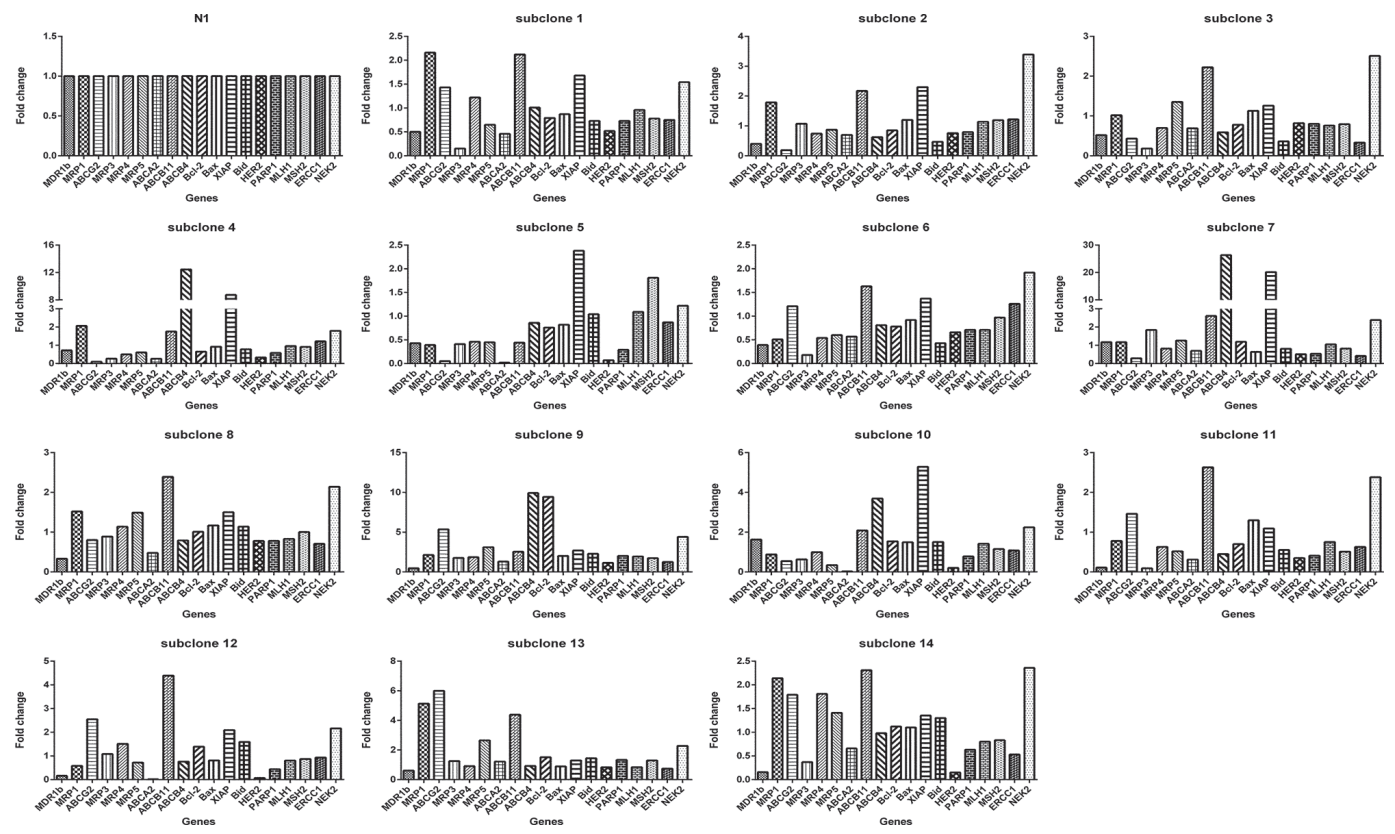

Figure 8: Each subclone derived from monoclonal N1 exhibits gene expression pattern distinct from others. Taking N1 as a reference, the relative expression level of the 19 genes in each subclone is based on the formula $2^{-[(\Delta \mathrm{CT}) \text { subclone(i)-( } \Delta \mathrm{CT}) \mathrm{N} 1]}$ according to the method previously described [39], where, subclone(i) denote any one of the 14 clones. $\Delta \mathrm{CT}$ was derived as described in Materials and Methods. 
Taken together, even a single cancer cell, through simple division, without exogenous stimuli, can quickly and randomly generate an array of daughter clones with diverse drug-response phenotypes. This might be an important way for cancer cells to acquire diversity of drug resistance, in addition to the classical intrinsic and acquired drug resistance. This observation unravels to some extent the elusive nature of cancer cells, which may potentially interfere with chemotherapy.

\section{MATERIALS AND METHODS}

\section{Chemicals}

RPMI 1640 and fetal calf serum, 0.25\% trypsin were purchased from GIBCO-BRL (Grand Island, NY, USA);TRIzol ${ }^{\circledR}$ reagent was purchased from Life Technologies, Inc. (Rockville, MD, USA); primer pairs were synthesized by Sangon Co. (Shanghai, People's Republic of China); iTaq $^{\mathrm{TM}}$ Universal SYBR Green ${ }^{\circledR}$ Supermix was purchased from Bio-Rad Laboratories, Inc. (Hercules, CA, USA).

\section{Cell culture}

Mouse breast cancer cell line (4T1) and human breast cancer cell line (Bcap37) were from the Cell Bank of the Chinese Academy of Sciences (Shanghai, China) and cultured in RPMI-1640 supplemented with 10\% fetal bovine serum (FBS) and antibiotics. All cells were grown in $37^{\circ} \mathrm{C}, 5 \% \mathrm{CO}_{2}$ in a humidified atmosphere.

\section{Clones from 4T1 or Bcap37 cell lines}

Using limited dilution method, 4T1 cells were seeded in the 96-well plate with average one cell per well. After 14 days, single cell clones were isolated and expanded in RPMI-1640 medium supplemented with 10\% fetal bovine serum (FBS) and antibiotics. The single cell clones from Bcap37 cells were acquired through the same method as 4T1.

\section{Subclones from a single 4T1 or Bcap37 cell}

Using limited dilution method, monoclonal 4T1 or Bcap37 cells described above were seeded in the 96well plate with average one cell per well. 14 days later, subclones were isolated and expanded in RPMI-1640 medium supplemented with $10 \%$ fetal bovine serum (FBS) and antibiotics.

\section{MTT assay}

Cytotoxicity was measured by MTT assay. Briefly, 4T1 cells were trypsinized and seeded into 96-well plates at a density of $4 \times 10^{3} /$ well and Bcap37 cells were seeded at a density of $8 \times 10^{3} /$ well overnight. Then a series of different concentrations of drugs were added to the cells. After 48 hours incubation, MTT (Sigma-Aldrich) was added with a work concentration of $0.5 \mathrm{mg} / \mathrm{ml}$. 4 hours later, $100 \mu \mathrm{l}$ triplex solution ( $10 \%$ sodium dodecyl sulfate (SDS), $5 \%$ isobutanol, $12 \mathrm{mmol} / \mathrm{L} \mathrm{HCl}$ ) was added to each well and continued to incubated in $37^{\circ} \mathrm{C}$ overnight. The plates were measured at $570 \mathrm{~nm}$ and a reference wavelength of $630 \mathrm{~nm}$ with a Bio-Rad model 680 microplate reader (Hercules, CA, USA). The percentage of cell survival was calculated by the following formula: percentage of cell survival $=$ (mean absorbance in test wells $) /($ mean absorbance in control wells $) \times 100 \%$. Half inhibitory concentration $\left(\mathrm{IC}_{50}\right)$ was determined [35].

\section{Real-time polymerase chain reaction}

4T1 cells, Bcap37 cells, or monoclonal cells (clones or subclones) were collected and RNA was prepared using the TRIzol ${ }^{\circledR}$ reagent according to the manufacturer's instruction [36]. The first strand cDNA was synthesized from extracted RNA using an Oligo dT as primer. Real time PCR reaction was carried out in $20 \mu 1$ system containing the cDNA, primers, $\mathrm{iTaq}^{\mathrm{TM}}$ Universal SYBR Green ${ }^{\circledR}$ Supermix, DEPC $\mathrm{H}_{2} \mathrm{O}$ and performed in a StepOne Plus ${ }^{\mathrm{TM}}$ machine (Applied Biosystems, Foster City, CA, USA). Primers sequences are listed in Supplementary table $4 \& 5$. A thermal profile of 30 second at $95{ }^{\circ} \mathrm{C}$, followed by 40 cycles of 15 seconds at $95{ }^{\circ} \mathrm{C}$ and 60 seconds at $60{ }^{\circ} \mathrm{C}$ with real-time fluorescence measured at the end of each annealing step was used. Melting curve analysis was performed on each run to confirm a single peak of activity for each primer pair [37]. The fluorescent signal was determined using StepOne Plus ${ }^{\mathrm{TM}}$ software (Applied Biosystems, Foster City, CA, USA), giving the threshold cycle number (CT) at which PCR amplification reached a significant threshold. The $\Delta \mathrm{CT}$ value is defined as the difference in CT value for the genes and GAPDH mRNA, the internal standard $[38,39]$.

\section{ACKNOWLEDGMENTS}

$\mathrm{XH}$ conceived the projects, designed the study, and wrote the paper. RW \& CJ performed the experiments.

The funders have no role in study design, in the collection, analysis, and interpretation of data, in the writing of the report, and in the decision to submit the paper for publication.

\section{CONFLICTS OF INTEREST}

All authors declare that there is no conflicts of interest. 


\section{GRANT SUPPORT}

This work has been supported in part by the China National 973 project (2013CB911303), China Natural Sciences Foundation projects (81272456 and 81470126) and the Fundamental Research Funds for the Central Universities, Ministry of Education, P.R. China, to XH.

\section{REFERENCES}

1. Gottesman MM, Fojo T, Bates SE. Multidrug resistance in cancer: role of ATP-dependent transporters. Nat Rev Cancer. 2002; 2: 48-58. doi: 10.1038/nrc706.

2. Holohan C, Van Schaeybroeck S, Longley DB, Johnston PG. Cancer drug resistance: an evolving paradigm. Nature Reviews Cancer. 2013; 13: 714-26. doi: 10.1038/nrc3599.

3. Marjanovic ND, Weinberg RA, Chaffer CL. Cell plasticity and heterogeneity in cancer. Clin Chem. 2013; 59: 168-79. doi: 10.1373/clinchem.2012.184655.

4. Marusyk A, Almendro V, Polyak K. Intra-tumour heterogeneity: a looking glass for cancer? Nat Rev Cancer. 2012; 12: 323-34. doi: 10.1038/nrc3261.

5. Hiley C, de Bruin EC, McGranahan N, Swanton C. Deciphering intratumor heterogeneity and temporal acquisition of driver events to refine precision medicine. Genome Biol. 2014; 15: 453. doi: 10.1186/ s13059-014-0453-8.

6. Baca SC, Prandi D, Lawrence MS, Mosquera JM, Romanel A, Drier Y, Park K, Kitabayashi N, MacDonald TY, Ghandi M, Van Allen E, Kryukov GV, Sboner A, et al. Punctuated evolution of prostate cancer genomes. Cell. 2013; 153: 66677. doi: 10.1016/j.cell.2013.03.021.

7. Dalerba P, Kalisky T, Sahoo D, Rajendran PS, Rothenberg ME, Leyrat AA, Sim S, Okamoto J, Johnston DM, Qian D, Zabala M, Bueno J, Neff NF, et al. Single-cell dissection of transcriptional heterogeneity in human colon tumors. Nat Biotechnol. 2011; 29: 1120-7. doi: 10.1038/nbt.2038.

8. McGranahan N, Swanton C. Biological and therapeutic impact of intratumor heterogeneity in cancer evolution. Cancer Cell. 2015; 27: 15-26. doi: 10.1016/j. ccell.2014.12.001.

9. Saunders NA, Simpson F, Thompson EW, Hill MM, Endo-Munoz L, Leggatt G, Minchin RF, Guminski A. Role of intratumoural heterogeneity in cancer drug resistance: molecular and clinical perspectives. Embo Molecular Medicine. 2012; 4: 675-84. doi: 10.1002/ emmm.201101131.

10. Marusyk A, Polyak K. Tumor heterogeneity: Causes and consequences. Biochimica Et Biophysica ActaReviews on Cancer. 2010; 1805: 105-17. doi: 10.1016/j. bbcan.2009.11.002.

11. Meyer M, Reimand J, Lan X, Head R, Zhu X, Kushida M, Bayani J, Pressey JC, Lionel AC, Clarke ID, Cusimano M, Squire JA, Scherer SW, et al. Single cell-derived clonal analysis of human glioblastoma links functional and genomic heterogeneity. Proc Natl Acad Sci U S A. 2015; 112: 851-6. doi: 10.1073/pnas.1320611111.

12. Kim KT, Lee HW, Lee HO, Kim SC, Seo YJ, Chung W, Eum HH, Nam DH, Kim J, Joo KM, Park WY. Singlecell mRNA sequencing identifies subclonal heterogeneity in anti-cancer drug responses of lung adenocarcinoma cells. Genome Biol. 2015; 16: 127. doi: 10.1186/ s13059-015-0692-3.

13. Cohen RL, Settleman J. From cancer genomics to precision oncology--tissue's still an issue. Cell. 2014; 157: 1509-14. doi: 10.1016/j.cell.2014.05.027.

14. Kreso A, O'Brien CA, van Galen P, Gan OI, Notta F, Brown AM, Ng K, Ma J, Wienholds E, Dunant C, Pollett A, Gallinger S, McPherson J, et al. Variable clonal repopulation dynamics influence chemotherapy response in colorectal cancer. Science. 2013; 339: 543-8. doi: 10.1126/ science. 1227670 .

15. Ruiz C, Lenkiewicz E, Evers L, Holley T, Robeson A, Kiefer J, Demeure MJ, Hollingsworth MA, Shen M, Prunkard D, Rabinovitch PS, Zellweger T, Mousses S, et al. Advancing a clinically relevant perspective of the clonal nature of cancer. Proc Natl Acad Sci U S A. 2011; 108: 12054-9. doi: 10.1073/pnas.1104009108.

16. Ding L, Ley TJ, Larson DE, Miller CA, Koboldt DC, Welch JS, Ritchey JK, Young MA, Lamprecht T, McLellan MD, McMichael JF, Wallis JW, Lu C, et al. Clonal evolution in relapsed acute myeloid leukaemia revealed by wholegenome sequencing. Nature. 2012; 481: 506-10. doi: 10.1038/nature10738.

17. Niepel M, Spencer SL, Sorger PK. Non-genetic cell-tocell variability and the consequences for pharmacology. Curr Opin Chem Biol. 2009; 13: 556-61. doi: 10.1016/j. cbpa.2009.09.015.

18. Sigal A, Milo R, Cohen A, Geva-Zatorsky N, Klein Y, Liron Y, Rosenfeld N, Danon T, Perzov N, Alon U. Variability and memory of protein levels in human cells. Nature. 2006; 444: 643-6. doi: 10.1038/nature05316.

19. Elowitz MB, Levine AJ, Siggia ED, Swain PS. Stochastic gene expression in a single cell. Science. 2002; 297: 1183-6. doi: 10.1126/science.1070919.

20. Raj A, van Oudenaarden A. Nature, Nurture, or Chance: Stochastic Gene Expression and Its Consequences. Cell. 2008; 135: 216-26. doi: 10.1016/j.cell.2008.09.050.

21. Spencer SL, Gaudet S, Albeck JG, Burke JM, Sorger PK. Non-genetic origins of cell-to-cell variability in TRAILinduced apoptosis. Nature. 2009; 459: 428-32. doi: 10.1038/ nature 08012.

22. Gascoigne KE, Taylor SS. Cancer cells display profound intra- and interline variation following prolonged exposure to antimitotic drugs. Cancer Cell. 2008; 14: 111-22. doi: 10.1016/j.ccr.2008.07.002.

23. Wu H, Ding Z, Hu D, Sun F, Dai C, Xie J, Hu X. Central role of lactic acidosis in cancer cell resistance to glucose deprivation-induced cell death. J Pathol. 2012; 227: 189-99. doi: 10.1002/path.3978. 
24. Xie J, Dai C, Hu X. Evidence That Does Not Support Pyruvate Kinase M2 (PKM2)-catalyzed Reaction as a Ratelimiting Step in Cancer Cell Glycolysis. J Biol Chem. 2016; 291: 8987-99. doi: 10.1074/jbc.M115.704825.

25. Xie J, Wu H, Dai C, Pan Q, Ding Z, Hu D, Ji B, Luo Y, Hu $\mathrm{X}$. Beyond Warburg effect--dual metabolic nature of cancer cells. Sci Rep. 2014; 4: 4927. doi: 10.1038/srep04927.

26. Wu H, Ying M, Hu X. Lactic acidosis switches cancer cells from aerobic glycolysis back to dominant oxidative phosphorylation. Oncotarget. 2016; 7:40621-40629. doi: 10.18632/oncotarget.9746.

27. Zhu $\mathrm{C}, \mathrm{Hu} \mathrm{W}, \mathrm{Wu} \mathrm{H}, \mathrm{Hu} \mathrm{X}$. No evident dose-response relationship between cellular ROS level and its cytotoxicity--a paradoxical issue in ROS-based cancer therapy. Sci Rep. 2014; 4: 5029. doi: 10.1038/srep05029.

28. Sun F, Dai C, Xie J, Hu X. Biochemical issues in estimation of cytosolic free NAD/NADH ratio. PLoS One. 2012; 7: e34525. doi: 10.1371/journal.pone.0034525.

29. Dai C, Sun F, Zhu C, Hu X. Tumor environmental factors glucose deprivation and lactic acidosis induce mitotic chromosomal instability--an implication in aneuploid human tumors. PLoS One. 2013; 8: e63054. doi: 10.1371/ journal.pone.0063054.

30. Liu Z, Zhang B, Liu K, Ding Z, Hu X. Schisandrin B attenuates cancer invasion and metastasis via inhibiting epithelial-mesenchymal transition. PLoS One. 2012; 7: e40480. doi: 10.1371/journal.pone.0040480.

31. Zhang $\mathrm{B}, \mathrm{Liu} \mathrm{Z}, \mathrm{Hu} \mathrm{X}$. Inhibiting cancer metastasis via targeting NAPDH oxidase 4. Biochem Pharmacol. 2013; 86: 253-66. doi: 10.1016/j.bcp.2013.05.011.

32. Cohen AA, Geva-Zatorsky N, Eden E, Frenkel-Morgenstern M, Issaeva I, Sigal A, Milo R, Cohen-Saidon C, Liron Y,
Kam Z, Cohen L, Danon T, Perzov N, et al. Dynamic proteomics of individual cancer cells in response to a drug. Science. 2008; 322: 1511-6. doi: 10.1126/science.1160165.

33. Gupta PB, Fillmore CM, Jiang G, Shapira SD, Tao K, Kuperwasser C, Lander ES. Stochastic state transitions give rise to phenotypic equilibrium in populations of cancer cells. Cell. 2011; 146: 633-44. doi: 10.1016/j.cell.2011.07.026.

34. Vermeer DW, Coppock JD, Zeng E, Lee KM, Spanos WC, Onken MD, Uppaluri R, Lee JH, Vermeer PD. Metastatic model of HPV+ oropharyngeal squamous cell carcinoma demonstrates heterogeneity in tumor metastasis. Oncotarget. 2016; 7: 24194-207. doi: 10.18632/oncotarget.8254.

35. Liu R, Wang M, Duan JA. Antipyretic and antioxidant activities of the aqueous extract of Cornu bubali (water buffalo horn). Am J Chin Med. 2010; 38: 293-306. doi: 10.1142/S0192415X10007853.

36. Bapat SA, Mali AM, Koppikar CB, Kurrey NK. Stem and progenitor-like cells contribute to the aggressive behavior of human epithelial ovarian cancer. Cancer Res. 2005; 65: 3025-9. doi: 10.1158/0008-5472.CAN-04-3931.

37. Bao L, Cardiff RD, Steinbach P, Messer KS, Ellies LG. Multipotent luminal mammary cancer stem cells model tumor heterogeneity. Breast Cancer Res. 2015; 17: 137. doi: 10.1186/s13058-015-0615-y.

38. Li L, Lu Q, Shen Y, Hu X. Schisandrin B enhances doxorubicin-induced apoptosis of cancer cells but not normal cells. Biochem Pharmacol. 2006; 71: 584-95. doi: 10.1016/j.bcp.2005.11.026.

39. Pan Q, Fang Y, Xu Y, Zhang K, Hu X. Down-regulation of DNA polymerases kappa, eta, iota, and zeta in human lung, stomach, and colorectal cancers. Cancer Lett. 2005; 217 : 139-47. doi: 10.1016/j.canlet.2004.07.021. 